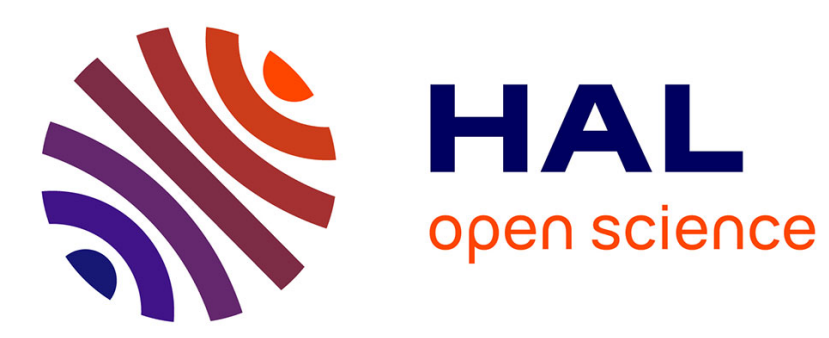

\title{
The Solstices and the Orientation of the Roman Fort of Segontium
}

Amelia Carolina Sparavigna

\section{To cite this version:}

Amelia Carolina Sparavigna. The Solstices and the Orientation of the Roman Fort of Segontium. SSRN : Social Science Research Network, 2017, 10.2139/ssrn.2990995 . hal-02284493

\section{HAL Id: hal-02284493 \\ https://hal.science/hal-02284493}

Submitted on 11 Sep 2019

HAL is a multi-disciplinary open access archive for the deposit and dissemination of scientific research documents, whether they are published or not. The documents may come from teaching and research institutions in France or abroad, or from public or private research centers.
L'archive ouverte pluridisciplinaire HAL, est destinée au dépôt et à la diffusion de documents scientifiques de niveau recherche, publiés ou non, émanant des établissements d'enseignement et de recherche français ou étrangers, des laboratoires publics ou privés. 


\title{
The solstices and the orientation of the Roman Fort of Segontium
}

\author{
Amelia Carolina Sparavigna \\ Politecnico di Torino
}

\begin{abstract}
Here we discuss the orientation of Segontium, the Roman fort of Caernarfon, North Wales. As all the Roman military camps, this fort was planned according to an ideal pattern that was also applied to the coloniae, the outposts established in the territories conquered by Rome. The planning of military camps and colonies was based on a grid of parallel and perpendicular streets, where the main of them, the Decumanus, was specifically aligned. Some scholars are arguing that the Decumani were oriented according to the opportunity and environmental conditions of the place, some others are proposing the possibility of an astronomical orientation, to confer a symbolic meaning to the place too. Here we show that Segontium, besides having a very good defensive position and related orientation, had also astronomical alignments along the directions of sunrise/sunset on solstices. In fact, it had the same distinctive layout of another military camp of Roman Britannia, the Hardknott Fort, the orientation of which along sunrise/sunset on solstices we have already proposed.
\end{abstract}

Keywords: Archeology, Archeoastronomy, Solar Orientation, Solstices, Urban Planning, Satellite Images, Google Earth.

Submitted SSRN June 22, 2017.

Segontium is the Roman fort of Caernarfon, a town and port on the eastern shore of the Menai Strait, in the North Wales. The fort probably takes the name from the Afon Seiont, the river that runs into the Menai Strait, but it is also possible that the name is connected to the Segontiaci, a British tribe mentioned by Julius Caesar [1]. Segontium, generally considered as one of the 28 cities of Britain listed in the "History of the Britons" [2-4], was founded in AD 77 or 78 by Gnaeus Julius Agricola, the Gallo-Roman general responsible for much of the Roman conquest of Britain [5]. Near the fort, the remains of a civilian settlement exist and a temple of Mithras, the Caernarfon Mithraeum. References on the archaeological studies of Segontium are given in [6-8].

As observed in [1], "unlike the medieval Caernarfon Castle that was built alongside the Seiont estuary more than a thousand years later, Segontium was situated on higher ground to the east giving a good view of the Menai Strait". In fact, using Google Earth, we can clearly see that the Roman surveyors decided the place of the fort to have the best defensive position, which allowed also the possibility to control both the strait and the land. In the Figures 1 and 2, we used two elevation profiles from Google Earth to verify this fact, with a method already used for other sites [9-11]. The lines chosen for the investigations and shown in the Figures are parallel to the streets of the fort. From these observations, it is possible to argue that the orientation of the fort was decided according to its specific position.

Segontium is one of the Roman forts, the orientation of which had been studied by the architect Gaetano Vinaccia in [12] (Vinaccia's works are discussed in [13-15]). As told in [13], in the book of 1939 Vinaccia discussed his theory on a strict relationship between the orientation of Roman cities and the local environmental conditions, "especially in relation to the winds". It is generally known that the Roman surveyors used a grid of parallel and perpendiculars streets for the urban planning of the towns, a planning that was used also for their military camps, the "castra", and for the limitation (centuriation) of the land [16]. Gaetano Vinaccia considered the Roman surveyors 
orienting the grid, "to also take into account the main directions of 'annoying' (cold) and 'unhealthy' (hot-humid) local winds in order to avoid their penetration into the urban spaces. Evidence of Vinaccia's theory is contained in ancient texts, such as Vitruvius's De Architectura and Hyginius Gromaticus's De Castris Romanis" [13]. However, as told in [13], Vinaccia was perfectly aware of the existence of additional orientations towards the oriens brumalis (southern sunrise) and aestivalis (northern sunrise) mentioned by Columella [17], that he, Vinaccia, considered from the point of view of a rationale sun exposure, especially for thermal opportunities.

Then, let us consider also the solar orientation of the Roman fort of Segontium. Here we give the results in the Figure 3. Thanks to Suncalc.org, we can see the direction of sunrise and sunset on any day of the year, depicted on a satellite map. In the panels of the Figure 3 , the orange line is representing the direction of the sunrise, and the red line the direction of the sunset. We can see also the apparent motion of the sun as described by the yellow curve. We have a good alignment of the buildings of the Roman fort, along the sunrise and sunset on the solstices. The Figure 4 is representing the sunrise/sunset on the solstices in the same image, obtained by means of two snapshots of the results displayed by Suncalc.org.

Some scholars, like Vinacchia, are arguing that the Decumani were oriented according to the opportunity and environmental conditions of the places, some others are proposing the possibility of an astronomical orientation, to confer a symbolic meaning to the place too [18-22]. In fact, it is usually told that the Decumanus, that is the main street of a town or of a centuriation, was usually east - west oriented. However, as specified by Francis Haverfield in his book on the ancient townplanning [18], it would be better to tell that the orientation was towards the sunrise, according to a ritual that involved the direction of the rising sun on the day of foundation. For this reason, the Decumanus could span the range of the sunrise azimuth between the directions on summer and winter solstices. Actually, we have several examples of towns oriented to the sunrise on solstices [23-27]. Consequently, the grid of the centuriation appears as astronomically oriented, and not oriented to the cardinal points. However, we have to note that, in many cases, an astronomical orientation is close to the best possible choice with respect to the geographical position of the site. In this manner, the astronomical orientation could have been used to add a symbolic meaning to the geolocal site.

In the Figure 4, we have combined two snapshots of the results given by Suncalc.org for the solstices. We did so to appreciate the solar arc, that is, the arc created by the sun rising and setting in a different spot on the horizon every day of the year [28]. The solar arc changes according to the latitude. For the latitude of Segontium, the sunrise and sunset azimuths on the summer solstice are 47 and 313 degrees respectively, and 130 and 230 degrees on the winter solstice (to have these angles, the Sollumis.com software can be used). The arcs of sunrise and sunset between these extremal values are corresponding to 83 degrees. For the latitude of Rome, the angles are quite different: the sunrise and sunset azimuths on the summer solstice are 57 and 304 degrees, and 122 and 239 degrees on the winter solstice. The arcs are corresponding to 65 degrees [28].

We have already observed the astronomical orientation shown in the Figure 4 for another Roman fort, the Hardknott fort of Mediobogdum, located on the western side of the Hardknott Pass [29]. Here, this fort is given in the Figure 5. The sunrise and sunset azimuths on the summer solstice are 46 and 315 degrees respectively, and 132 and 229 degrees on the winter solstice. The arcs of sunrise and sunset between the extremal values are corresponding to 86 degrees. To the latitude of Mediobogdum, this angle is close to the 90 degrees of a square layout. In [29], we concluded that, for Mediobogdum, the surveyors of the Roman army had decided the best strategic place for the military camp and given it a perfect square figure, aligned to solstices. In this manner, they had the opportunity of paying homage to the gods ruling the sky and the sun, may be, the Sol Invictus, patron 
of the soldiers, or Mithras, whose Mysteries were a religion popular in the Roman army. Both Sol Invictus and Mithras, who were often identified in the same god [30], are linked to the winter solstice [31-33].

Here we can repeat the same for Segontium. It is possible that the fort was oriented according to the winter solstice, besides being aligned along the best geolocal configuration. There is another important fact, which is supporting this conclusion: the existence of a temple of Mithras, the Caernarfon Mithraeum, near the fort. It means that the site was particularly devoted to this god and that, probably, people worshipped the New Year of the Mysteries, on December 25 [34]. In the simulations by means of Suncal.org, the direction of the sunrise on December 25 is not appreciably different from that observed on solstice. For this reason, local people had also the alignment of the streets along the sunrise to recall the birth of Mithras.

\section{References}

[1] Vv. Aa. (2017). Wikipedia, https://en.wikipedia.org/wiki/Segontium

[2] Mommsen, T., Editor. Historia Brittonum, VI. Composed after AD 830. Hosted at Latin Wikisource

[3] Ford, D. N. (2000). The 28 Cities of Britain, at Britannia.

[4] Newman, J. H. \& al. (1844). Lives of the English Saints: St. German, Bishop of Auxerre, Ch. X: Britain in 429, AD , p. 92. James Toovey (London).

[5] Vv. Aa. (2017). Wikipedia, https://en.wikipedia.org/wiki/Gnaeus_Julius_Agricola

[6] Frances Lynch (1995). A guide to ancient and historic Wales: Gwynedd (HMSO)

[7] R.E. Mortimer Wheeler (1924). Segontium and the Roman occupation of Wales. Honourable Society of Cymmrodorion.

[8] Vv. Aa. (2016). Segontium. http://roman-britain.co.uk/places/segontium.htm

[9] Sparavigna, A. C. (2017). The Ancient Norba and the Solstices (January 7, 2017). Available at SSRN: https://ssrn.com/abstract=2895354 or http://dx.doi.org/10.2139/ssrn.2895354

[10] Sparavigna, A. C. (2016). The Italic Sanctuary of Monte Torre Maggiore and the Sky (December 18, 2016). Available at SSRN: https://ssrn.com/abstract $=2887082$ or http://dx.doi.org/10.2139/ssrn.2887082

[11] Sparavigna, A. C. (2016). The Temple Complex of Ggantija and the Major Lunar Standstill as Given by the Photographer's Ephemeris (August 24, 2016). Available at SSRN: https://ssrn.com/abstract=2828614 or http://dx.doi.org/10.2139/ssrn.2828614

[12] Vinaccia, G. (1939). Il problema dell'orientamento nell'urbanistica dell'antica Roma (Vol. 1). Istituto di studi romani.

[13] Giovagnorio, I., Usai, D., Palmas, A., \& Chiri, G. M. (2017). The environmental elements of foundations in Roman cities: A theory of the architect Gaetano Vinaccia. Sustainable Cities and Society, 32, 42-55.

[14] Chiri, G., \& Giovagnorio, I. (2015). Gaetano Vinaccia's (1881-1971) Theoretical Work on the Relationship between Microclimate and Urban Design. Sustainability, 7(4), 4448-4473.

[15] Chiri, G., \& Giovagnorio, I. L. A. R. I. A. (2014). Microclimate and Forma Urbis. The Topicality of Gaetano Vinaccia's Theoretical Work (1881-1971). Recent Advances in Urban Planning, Sustainable Development and Green Energy.

[16] Sparavigna, A. C. (2015). Roman Centuriation in Satellite Images (December 26, 2015). PHILICA Article number 547. Available at SSRN: https://ssrn.com/abstract=2742223

[17] Fallanca, C. (2016). Gli dèi della città. Progettare un nuovo umanesimo: Progettare un nuovo umanesimo, Franco Angeli Editore.

[18] Haverfield, F. (1913). Ancient town-planning. The Clarendon Press. 
[19] Barthel, W. (1911). Römische Limitation in der Provinz Africa, 1911, CXX, pp. 39-126. Carl Georgi Verlag, Bonn.

[20] Bonine, M. E. (2008). Romans, Astronomy and the Qibla: Urban Form and Orientation of Islamic Cities of Tunisia. In African Cultural Astronomy: Current Archaeoastronomy and Ethnoastronomy Research in Africa (pp. 145-178). J., Medupe, R. T., \& Urama, J. O. (Eds.). Springer Science \& Business Media.

[21] Aveni, A., \& Romano, G. (1994). Orientation and Etruscan ritual. Antiquity, 68(260), 545-563.

[22] Magli, G. (2008). On the orientation of Roman towns in Italy, Oxford Journal of Archeology, 27 (1), 63-71.

[23] Sparavigna, A. C. (2016). Roman Towns Oriented to Sunrise and Sunset on Solstices. Available at SSRN: https://ssrn.com/abstract=2777118 or http://dx.doi.org/10.2139/ssrn.2777118

[24] Sparavigna, A. C. (2016). The Town Planning of Pompeii and Herculaneum Having Streets Aligned Along Sunrise on Summer Solstice. Available at SSRN: https://ssrn.com/abstract=2802439 or http://dx.doi.org/10.2139/ssrn.2802439

[25] Sparavigna, A. C. (2016). I Castra Albana Orientati Verso II Solstizio D' Estate (The Castra Albana Oriented to the Summer Solstice). PHILICA Article number 632. Available at SSRN: https://ssrn.com/abstract=2808242

[26] Sparavigna, A. C. (2017). L'antico tracciato urbano di Venafro ed il solstizio d'estate. 2017. <hal01538368>

[27] Sparavigna, A. C. (2107). The Walled Town of Alife and the Solstices. Philica, Philica, 2017. Available HAL, <hal-01464777>

[28] Sparavigna, A. C. (2017). The Hexagon of Portus Traiani and Its Link to the Solar Arc and the Ancient Wind Rose. Available at SSRN: https://ssrn.com/abstract $=2943871$ or http://dx.doi.org/10.2139/ssrn.2943871

[29] Sparavigna, A. C. (2014). Solstices at the Hardknott Roman Fort (December 17, 2014). PHILICA Article number 442 . Available at SSRN: https://ssrn.com/abstract $=2745184$

[30] Adkins, L., \& Adkins, R. A. (2014). Handbook to Life in Ancient Rome. Infobase Publishing.

[31] Heinberg, R. (2014). Celebrate the Solstice: Honoring the Earth's Seasonal Rhythms through Festival and Ceremony, Quest Books, Jan 29, 2014

[32] Wolfe, A., \& Davidson, A. (2010). Light on the Land. Simon and Schuster.

[33] Insoll, T. (1999). Case studies in archaeology and world religion: the proceedings of the Cambridge Conference, Volumes 755-766. Archaeopress.

[34] Vermaseren, M. J. (2011). The Excavations in the Mithraeum of the Church of Santa Pricsa in Rome. Brill. 


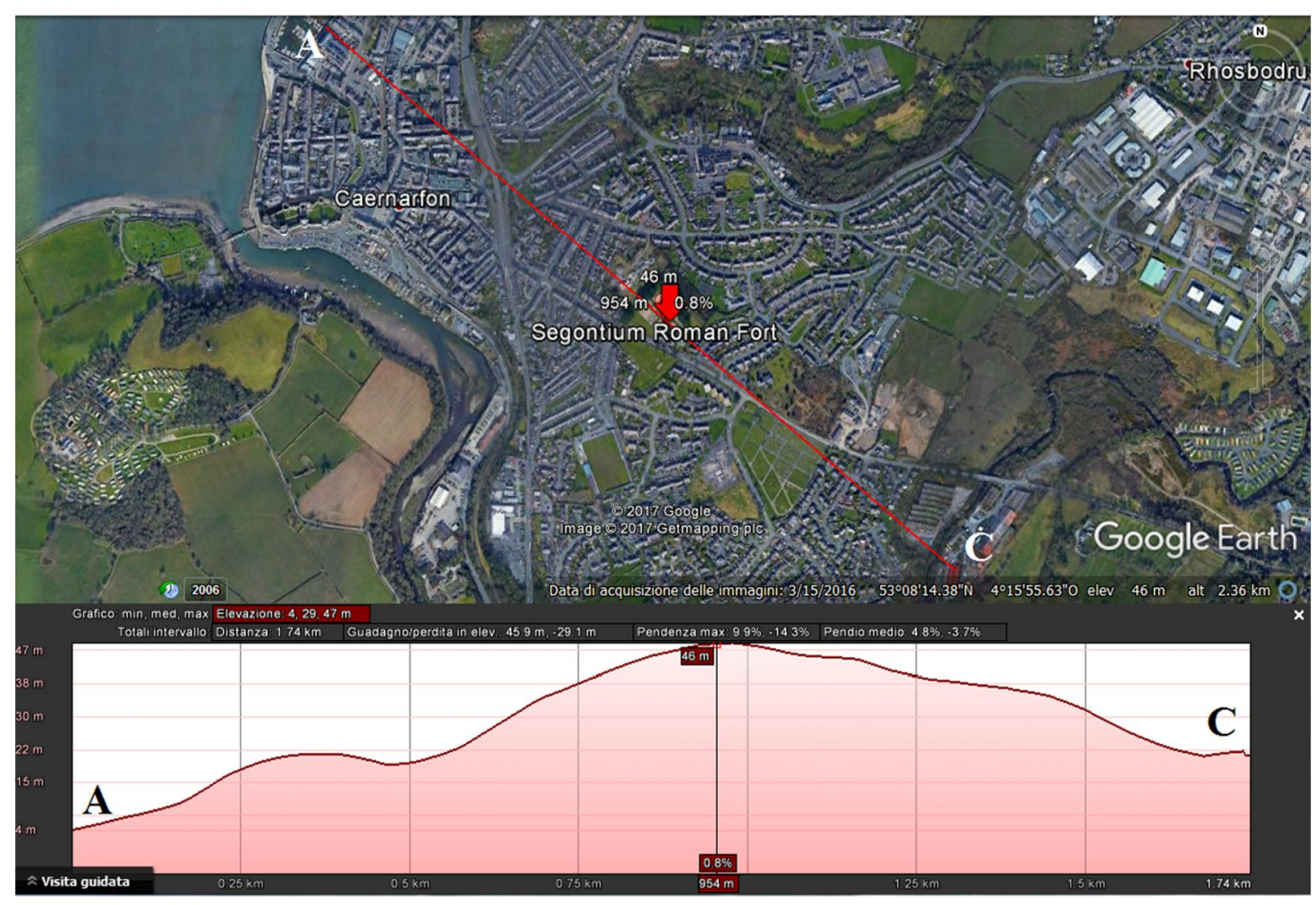

Figure 1: As observed in [1], "unlike the medieval Caernarfon Castle that was built alongside the Seiont estuary more than a thousand years later, Segontium was situated on higher ground to the east giving a good view of the Menai Strait". Using Google Earth, we can see the local elevation profile. We can appreciate that the Romans decided to occupy the best defensive position, which allowed also the possibility to control both the strait and the land.

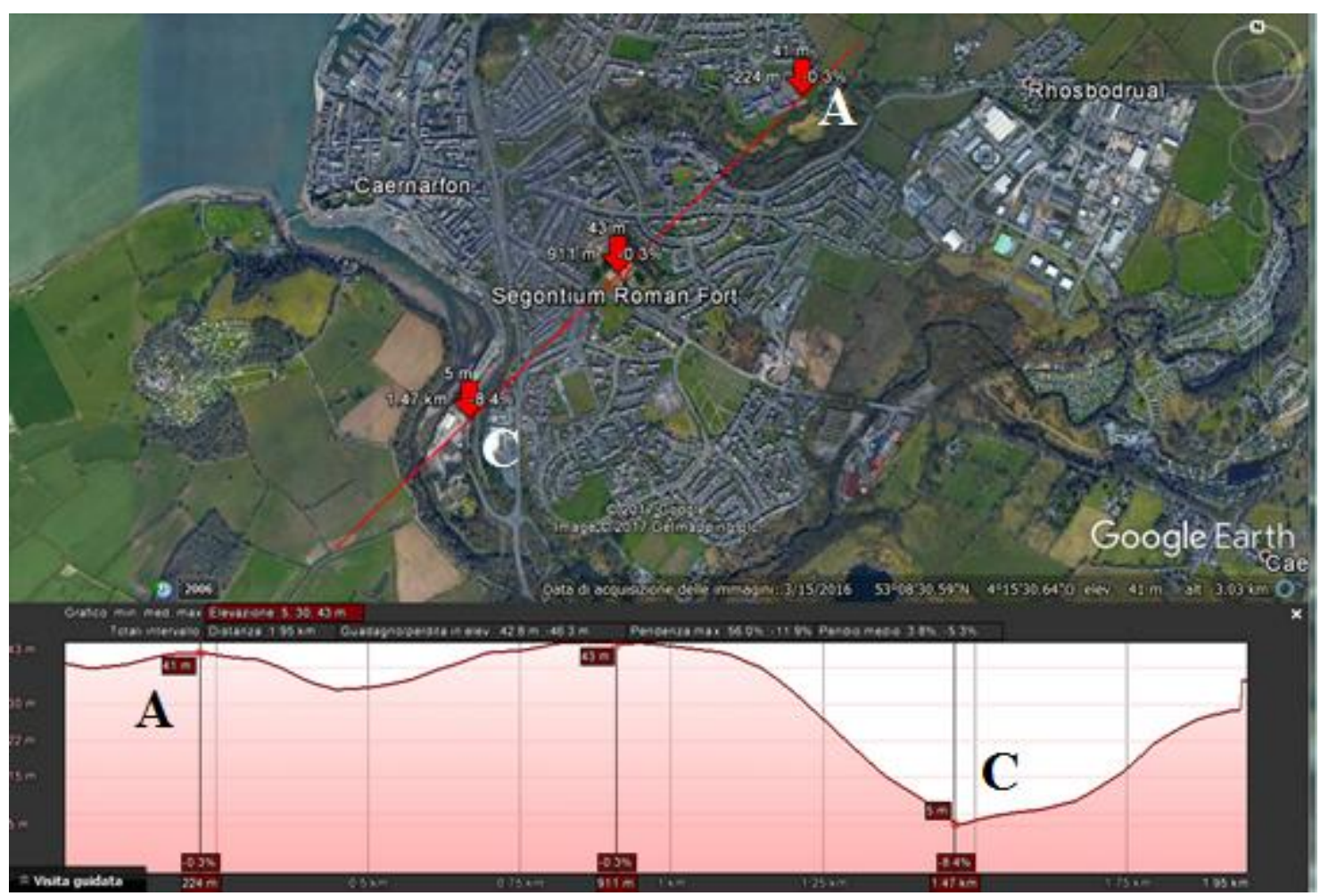

Figure 2: Another elevation profile obtained by means of Google Earth. 

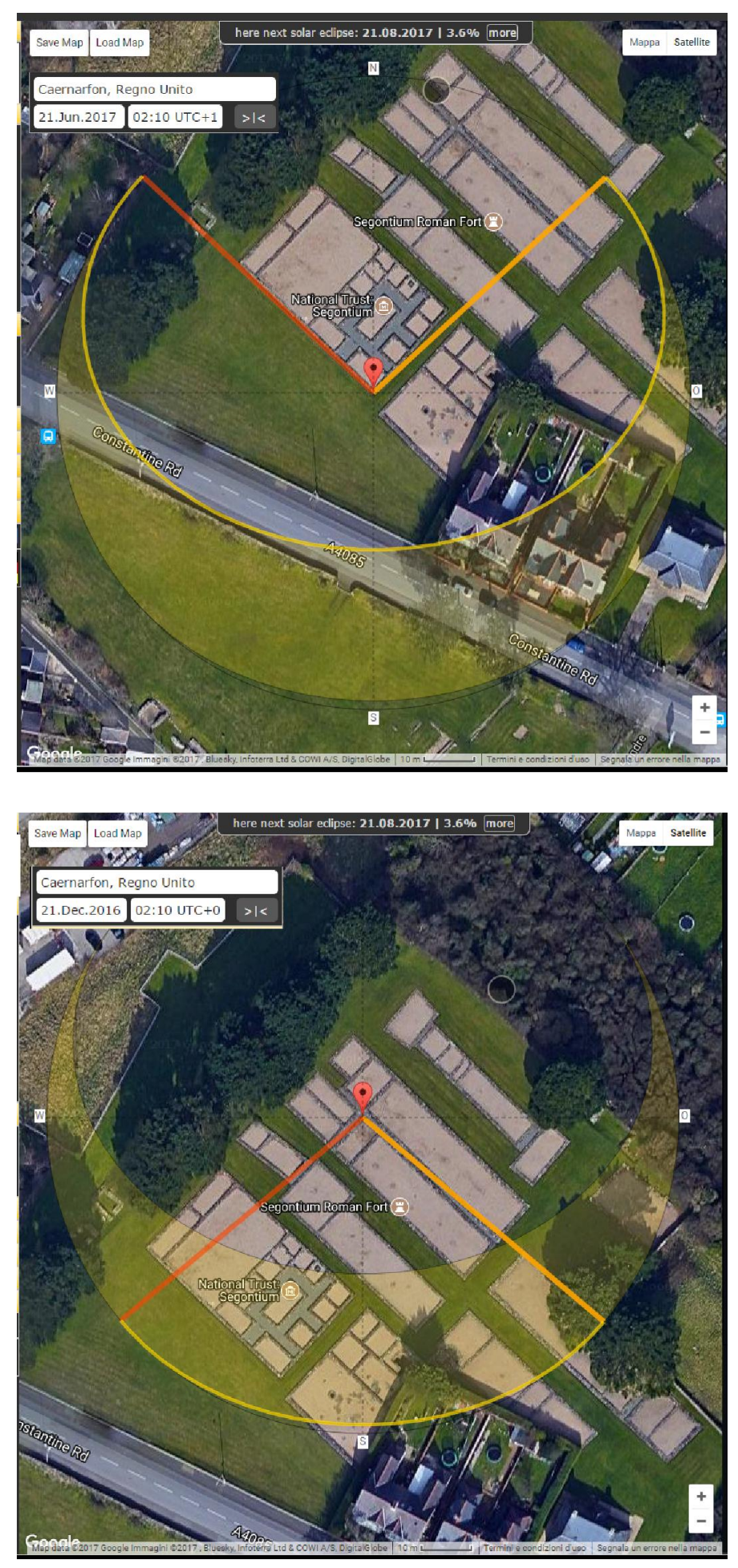

Figure 3: Thanks to Suncalc.org we can see the direction of the sunrise/sunset on solstices, depicted on a satellite map. Here we can see the Roman fort of Segontium. The orange line is representing the direction of the sunrise, and the red line the direction of the sunset. We can see also the apparent motion of the sun as described by the yellow curve. The upper panel is showing sunrise and sunset on the summer solstice and the lower panel the same on the winter solstice. 


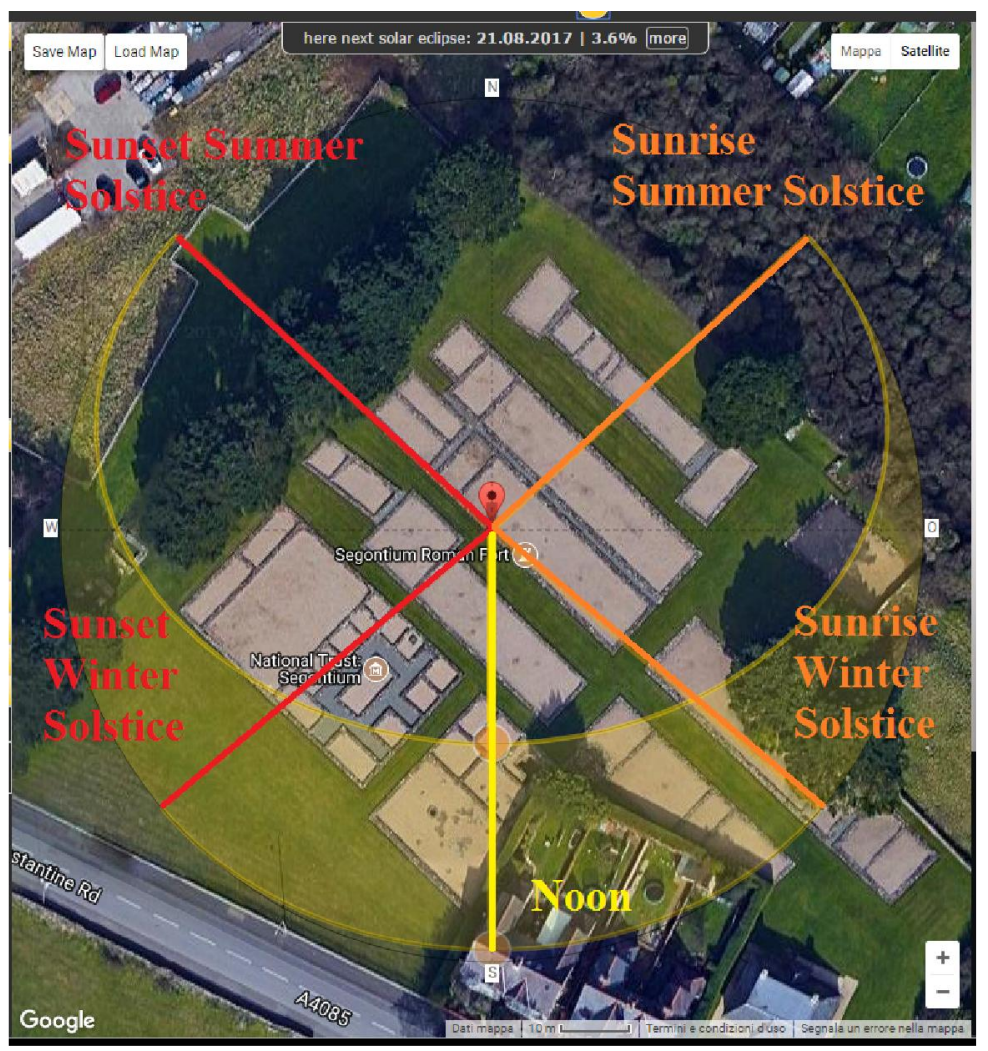

Figure 4: Two Suncalc.org snapshots combined to see the solar arc of the sun at the Roman fort of Segontium.

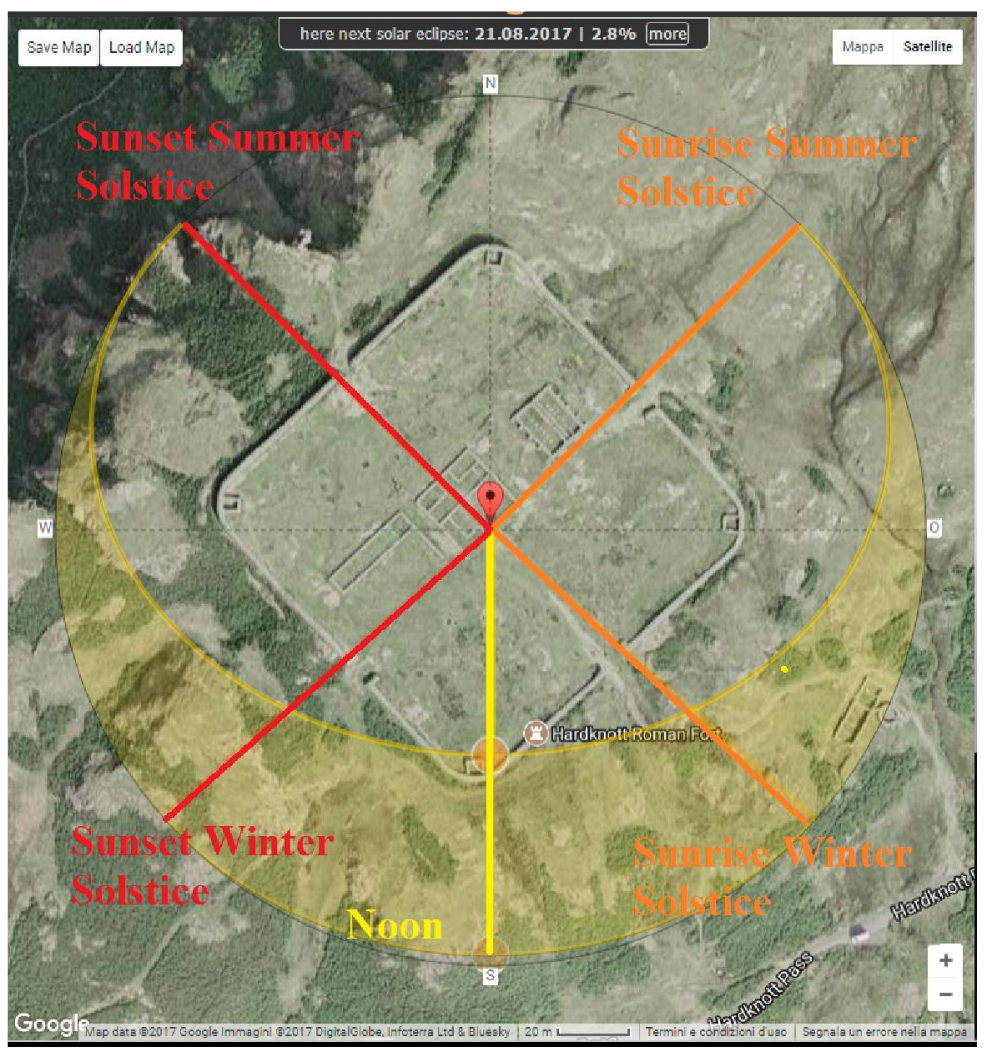

Figure 5: The same as in the Figure 4 for the Hardknott Roman fort. 